\title{
Low birth weight, family income and paternal absence as risk factors in neuropsychomotor development
}

Open acess

${ }^{1}$ Physiotherapist, Master in Motor Behavior and $\mathrm{PhD}$ student in Physical Activity and Health at UFPR.

${ }^{2}$ Physiotherapist, $\mathrm{PhD}$ student in Physical Activity and Health at UFPR; physiotherapist in the Municipality of Paranaguá, Professor at Uniandrade and IBRATE.

${ }^{3}$ Physiotherapist, $\mathrm{PhD}$ in Special Education at Federal University of São Carlos (UFSCar), Brazil. Associate Professor at Federal University of Paraná (UFPR) in the Graduate Program in Physical Education of UFPR.

\section{Corresponding author:}

luizebueno@hotmail.com

Manuscript received: 21 March 2017 Manuscript accepted: 20 June 2017 Version of record online: 06 December 2017

\section{Luize Bueno de Araujo1, Tainá Ribas Mélo², Vera Lúcia Israel³}

\begin{abstract}
Introduction: The first years of life are crucial to neuropsychomotor development (NPMD), during this period children are susceptible to organic, environmental or activity-related influences that may represent protective or risk factors towards full development, with potential lifelong repercussions.
\end{abstract}

Objective: This study aimed to investigate and verify the risk factors in the NPMD of children aged from zero to three years, attending public early childhood education centers.

Methods: Cross-sectional study, contextual approach - based on ICF (International Classification of Functioning, Disability and Health) -, Denver II developmental screening test and additional assessments about nutritional status. For the analysis, a logistic regression was performed. The ICF concerning body functions and structure (evaluation questionnaire), activity and participation (evaluation of NPMD in school), personal factors (family characteristics), and environmental factors (characteristics of the ECECs) were considered for the evaluation phase. The instruments consisted of a questionnaire containing items to elicit information about the child, including current, neonatal and family traits. For the evaluation DPMD, the Denver II test was used. Inter- and intra-rater reliability was established using Cohen's kappa, and data subsequently submitted to stepwise (backward) regression analysis using a Logit model, using binary responses. The construction of an ROC (Receiver Operating Characteristic) to define the explanatory profile of the model built also was included, in addition to the calculation of the Odds Ratio (OR), the odds of chance occurrence the association of a given variable with DPMD.

Results: NPMD was within the normal parameters, in $68.8 \%$ (n $=53)$ and risk of delays was in $31.2 \%(n=24)$. The area with the best performance was the fine motor-adaptive $(3.75 \%)$ and the most questionable one was the language $(57.5 \%)$. It was verified that $48 \%$ $(n=37)$ of the children had normal weight while $52 \%(n=40)$ presented some nutritional risk. Low birth weight $(\mathrm{OR}=181)$, monthly family income $(O R=9)$ and paternal absence $(O R=34)$ were statistically significant factors on the risk of NPMD delays.

Conclusion: Low birth weight, family income and paternal absence are factors associated with risks of NPMD delays. These findings reinforce the systemic and multifactorial nature of NPMD and emphasize the need for monitoring and formulating public policies -- especially the ones dedicated to children with low income conditions --, which could contribute to the full development of children, since public early childhood education centers should be transforming agents in the quality of child development.

Keywords: physical therapy specialty, child development, early childhood education, health promotion 


\section{INTRODUCTION}

The first years of life are critical to the neuropsychomotor development (NPMD), during this period which children are more likely to be influenced by factors ${ }^{1}$ that can be either risky or protective in the promotion of full development. Such factors can also impact their adulthood in the future ${ }^{2}$. Motor capacity is considered a good indicator for measuring child development ${ }^{3}$ as it can express not only neurological integrity and motor development, but also aspects of affectivity, cognition and social interaction with the environment $t^{4}$. This dynamic and complex process is currently explained by the context model, which considers individual biological aspects, environmental conditions and tasks' characteristics as essential components to understanding NPMD. The World Health Organization (WHO) proposes this same perspective through the International Classification of Functioning, Disability and Health (ICF) model ${ }^{5}$.

There is plenty of evidence ${ }^{6-8}$ that the environment in which the child is inserted, the stimuli provided and the biological characteristics impact NPMD leading to a cumulative effect of these factors ${ }^{9}$.

In Brazil - an developing country, where risks of NPMD delays are higher in children under five years old ${ }^{10}$ because of economic ${ }^{11}$ and social factors - full-time Early Childhood Education Centers (where children spend 8 to

\section{METHODS}

This observational, analytical and cross-sectional study was approved by the Ethics Research Committee of the Health Sciences Sector of Federal University of Paraná (UFPR), registry CEP / SD: 531.068.08.05 CAAE: 1212.0.000.091-8.

This study included children aging from 0 to 3 years enrolled in public Early Childhood Education Centers (ECECs) in Matinhos (PR), whose parents or guardians signed the Informed Consent Term. Exclusion criteria were: 1) children with neurological alterations, genetic syndromes or congenital malformations; 2) three absences during the evaluation process and 3) impossibility of carrying out the study's assessment, prepared as suggested by other studies that analyzed NPMD ${ }^{19-21}$.

For the sample calculation ${ }^{22}, 75$ children with ages from 0 to 3 years enrolled in the early childhood education centers during the period of the study were considered. The estimated probability of finding alterations was $15 \%$, with a sampling error of $5 \%$ and a confidence interval of $95 \%$.

During the period of screening and evaluation, the ICF criteria about functions and structure (through evaluation questionnaire) were considered, as well as activities and participation (through NPMD evaluation by Denver II in the school environment), personal characteristics (through family questionnaire) and environmental factors (characteristics of Early Childhood Education Centers).

The evaluation tool was a questionnaire to parents and/ or guardians about the children, their current characteristics, information about neonatal diseases and their families. To evaluate the neuropsychomotor development, the original version of Denver $\mathrm{II}^{23}$, adapted to Portuguese ${ }^{24}$, was used. This test was applied by three trained evaluators and
10 hours a day) are chosen 9 . Although most of them have unsatisfactory quality ${ }^{12}$, they still give indications of having a possible protective effect on the child development ${ }^{2}$, especially for children at social risk ${ }^{13}$. Given this situation, it is necessary to investigate risk and protective factors that influence development in this initial and crucial stage, with the objective of identifying and screening children exposed to these factors. This investigation could serve as a way to promote a satisfactory development, with experience and optimization of all their capabilities ${ }^{14,15}$, especially in the home/school spheres ${ }^{9}$, which are close environments convenient to be investigated.

In addition, it is noteworthy that the assessment of children in their everyday environments values the "ecological validity "for its proximity to the real environment ${ }^{16}$, having the potential to explain the variation of 59\% in NPMD in terms of activity and participation ${ }^{17}$. Activity is considered the execution of a task individually, while participation is related to such execution in a real environment ${ }^{18}$. Since the coastal region of Paraná has Human Development Index (HDI) of 0.73, which is considered average, it was an interesting scenario for the research.

Thus, the objective is to analyze the neuropsychomotor development of children with ages between zero and three years and the risk factors associated with their developments.

calibrated in accordance with the Kappa coefficient of intrarater and inter-rater agreement. To assess the nutritional status, anthropometric measurements such as weight and height were used by an assessor with appropriate intra-rater agreement coefficient (ICC- Intraclass Correlation Coefficient). To classify the nutritional status, the $\mathrm{WHO}^{25}$ reference standard, which is more updated and suitable for monitoring growth, was used through the $\mathrm{Z}$ score.

At the end of the study, all of the children's teachers and guardians attending the Early Childhood Education Centers were invited to participate in a meeting that aimed at showing and explaining the results without exposing any child participating in the research, who also received stimulation tips. The details of the individual assessments of each child were not considered. In the cases where the risk was identified, a meeting with the child's parents and/or guardians was requested so that the appropriate referrals were made. This step was divided into two phases, the first in which the intervention was held among educators and caretakers of the ECECs, and the second in which the intervention was held among family members and/or guardians of the children who frequented the ECECs study.

The statistical analysis was performed following the assessment of the development of participating children, in order to test the association between child development and the variables studied. In this step, logistic regression was applied using logit model selection with binary response and backward stepwise method, carrying out the maximization of the likelihood function with the Newton-Raphson algorithm, using the XLSTAT software (version 2012.1.01). For this analysis, the binary response variable used was normal neuropsychomotor development or questionable 
neuropsychomotor development. The following information were regarded as explanatory variables: current characteristics of the child(age, sex, ECEC, the time spent on the ECEC - full or part-time - and nutritional status); neonatal and gestational characteristics(birth weight, gestational age, miscarriages and type of delivery); family features (monthly family income, parental education, amount of time the child spends with the father and the mother daily, single mother and absence of the father) and the ECECs's characteristics (number of educators per child and time of activity of educators in ECECs).

Once the final logistic regression model was decided on, the odds were calculated from the formula $\operatorname{Pr}=1 /[1+$ and- $(\alpha+\Sigma$ ( $\beta$ i xi)], with $\alpha$ being the constant of the model. A ROC curve (Receiver Operating Characteristic) was built to define the justifiability profile of the model. Also included in the calculation was the Odds Ratio (OR), that is, the odds ratio of occurrence of a variable to be associated with the neuropsychomotor development, estimated by confidence intervals of $95 \%$. The analysis was completed with the calculation of the risk probability, by the estimate of the probability of occurrence of neuropsychomotor development delay, given the combination of the variables chosen for the predictive model. Significant explanatory variables with probability less than or equal to the significance level $(\mathrm{p} \leq$ $0.05)$ were considered. Anthropometric data were analyzed using Epi-Info 6 software, version 6.04, which gives the exact value of the Z-score of each individual. Integrated to the previous sentence.

\section{RESULTS}

This study included 77 children from 6 to 36 months of age of both sexes, who were enrolled in municipal public education in the town of Matinhos/Paraná and

frequented the ECECs A, B or C. The characteristics of the sample are shown in Table 1.

In this sample, $68.8 \%(n=53)$ of children presented

Table 1: Frequencies of categories of variables of the sample characterization.

\begin{tabular}{|c|c|c|c|c|}
\hline & Variables & Categories & Frequencies (n) & $\%$ \\
\hline \multirow[t]{12}{*}{ Current characteristics of the child } & Sex & Male & 40 & 52 \\
\hline & & Female & 37 & 48 \\
\hline & & 7 to 12 months & 12 & 15.58 \\
\hline & & 13 to 18 months & 19 & 24.68 \\
\hline & Age & 19 to 24 months & 17 & 22.08 \\
\hline & & 25 to 30 months & 13 & 16.88 \\
\hline & & 31 to 36 months & 16 & 20.78 \\
\hline & & A & 22 & 28.6 \\
\hline & ECEC & B & 12 & 15.6 \\
\hline & & C & 43 & 55.8 \\
\hline & & Full-time on ECEC & 39 & 50.65 \\
\hline & Period & Part-time on ECEC & 38 & 49.35 \\
\hline \multirow[t]{8}{*}{ Neonatal and gestational characteristics } & Birth weight* & $>2,500 \mathrm{Kg}$ & 70 & 90.91 \\
\hline & & $</=2.500 \mathrm{Kg}$ & 7 & 9.09 \\
\hline & Gestational age & > 37 weeks & 62 & 80.52 \\
\hline & & $</=37$ weeks & 15 & 19.48 \\
\hline & Abortions & Presence & 13 & 16.88 \\
\hline & & Absence & 64 & 83.12 \\
\hline & Delivery type & Normal & 24 & 31.17 \\
\hline & & Cesarean or other & 53 & 68.83 \\
\hline \multirow[t]{14}{*}{ Family characteristics } & Monthly household income ${ }^{*}$ & $<\mathrm{R} \$ 2,000.00$ & 46 & 59.74 \\
\hline & & $>/=\mathrm{R} \$ \$ 2,000.00$ & 31 & 40.26 \\
\hline & Educational status of the father & $<=$ Primary school concluded & 33 & 42.86 \\
\hline & & $>$ Primary school concluded & 44 & 57.14 \\
\hline & Educational status of the mother & $<=$ Primary school concluded & 16 & 20.78 \\
\hline & & $>$ Primary school concluded & 61 & 79.22 \\
\hline & Daily time the child spent with the & $<1$ period & 24 & 31.17 \\
\hline & father & $>/=1$ period & 53 & 68.83 \\
\hline & Daily time the child spent with mother & $<1$ period & 8 & 10.39 \\
\hline & & $>/=1$ period & 64 & 89.61 \\
\hline & Single mother & Yes & 21 & 27.27 \\
\hline & & No & 56 & 72.73 \\
\hline & Absent father* & Yes & 20 & 25.97 \\
\hline & & No & 57 & 74.03 \\
\hline \multirow[t]{4}{*}{ Characteristics of ECEC } & Number of educators per child & Suitable & 2 & 20.00 \\
\hline & & Inappropriate & 8 & 80.00 \\
\hline & Time of activity of educators in ECECs & $</=1$ year & 3 & 30.00 \\
\hline & & $>1$ year & 7 & 70.00 \\
\hline
\end{tabular}

*variables with interactions through the ROC curve (Figure 1). Source: the authors. 
normal neuropsychomotor development while $31.2 \%$ ( $\mathrm{n}=$ 24) presented questionable NPMD. From the 24 children with questionable development, 7 children (29.2\%) presented a shift in only one area of development, 12 $(50 \%)$ in two areas, $3(12.5 \%)$ in three areas and $2(8.3 \%)$ in all four areas. Analyzing the questionable sample and considering both the risks and delays, the language area was discovered as the most questionable $(57.5 \%)$, followed by the personal-social area, with $28.75 \%$, then the motor-gross (10\%) area, and the least affected was the fine-adaptive motor area, with $3.75 \%$.

In nutritional evaluation, it was determined that
$48 \%(n=37)$ of children were eutrophic and $52 \%(n=40)$ presented some nutritional risk. 1 child $(1.3 \%)$ presented early malnutrition, 25 children $(32.5 \%)$ were at risk of overweight and 14 children (18.2\%) were obese.

The results obtained by the combination of all the variables previously presented by means of logistic regression show that the model has a proper fit $(\mathrm{AIC}=82.739)$. The estimated probabilities were sorted and plotted on a chart, providing the ROC curve (Figure 1). The area under the ROC curve shows that the estimated probabilities model can predict approximately $93.5 \%$ of the events (Figure 1).

Figure 1: ROC curve (Receiver Operating Characteristics) generated by the validation of the logistic regression model.

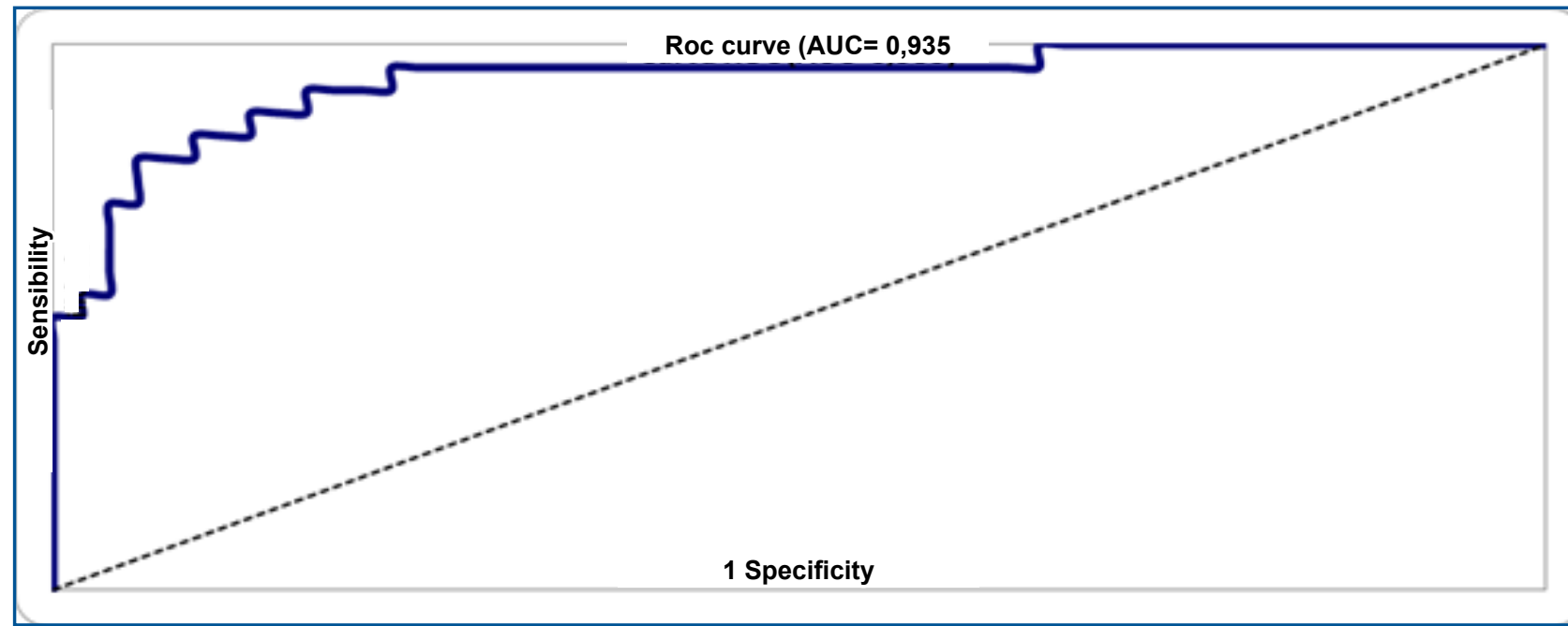

Source: the authors.

After the inclusion of the variables, according to the method of backward stepwise logistic regression, the final model was defined regarding the set of variables which contributed significantly to explain why children presented a questionable screening test of Denver II.

In the tests performed to evaluate possible interactions among variables, there was an association among birth weight $(\mathrm{OR}=181.0$; IC 95\% $1.902-$ $17,229.589 ; \mathrm{p}=0.025)$, monthly household income (OR $=9.90 ;$ IC 95\% $1.115-87.926 ; \mathrm{p}=0.040)$ and absence of the father $(\mathrm{OR}=34.51$; IC 95\% $1.033-1,153.490, \mathrm{p}=$ $0.048)$. It can be interpreted that the interaction between birth weight, monthly household income and absence of the father proved to be highly associated with delayed neuropsychomotor development, indicating that children with low birth weight, monthly household income lower than $\mathrm{R} \$ 2,000.00$ and absence of the father were approximately 181,9 to 34 times, more likely to report questionable development (Table 2).

Table 2: Parameters obtained through the application of logistic regression to identify the Odds Ratio for suspected delay in neuropsychomotor development.

\begin{tabular}{|lccccccc|}
\hline & Value & $\begin{array}{c}\text { Standard } \\
\text { error }\end{array}$ & $X^{2}$ of Wald & PR $>X_{2}$ & $\begin{array}{c}\text { Odds Ratio } \\
\text { (OR) }\end{array}$ & $\begin{array}{c}\text { OR Limit inf. } \\
\text { (95\%) }\end{array}$ & $\begin{array}{c}\text { OR Limit sup. } \\
\text { (95\%) }\end{array}$ \\
\hline Linear coefficient & -4.464 & 1.667 & 7.169 & 0.007 & & & \\
Birth weight & 5.199 & 2.324 & 5.001 & 0.025 & 181.004 & 1.902 & 17229.589 \\
$\begin{array}{l}\text { Monthly household } \\
\text { income }\end{array}$ & 2.293 & 1.114 & 4.234 & 0.040 & 9.901 & 1.115 & 87.926 \\
Absent father & 3.541 & 1.790 & 3.912 & 0.048 & 34.511 & 1.033 & 1153.490 \\
\hline
\end{tabular}

$\mathrm{OR}=$ odds ratio. Source: the authors.

\section{DISCUSSION}

During the analysis of NPMD, the biological component related to structure and functions, and the activity and participation, conducted through the Denver II test, a relevant portion of the sample (31.2\%) presented questionable results. Such results were similar to other studies in ECECs $(22.7 \%)^{26}$ and in other environments
$(27.3 \%)^{27}$, such as Halpern et al. ${ }^{11}(34 \%)$ and Torquato et al..$^{28}(31.6 \%)$. Therefore, research of identification and monitoring of the NPMD and its associated factors in early stages of life is clearly relevant ${ }^{9}$.

When investigating personal and environmental components of each child, it was observed, by means 
of logistic regression, that birth weight, monthly family income and paternal absence are risk factors influencing the neuropsychomotor development of the children evaluated. Although the proportions differed in each of the variables, the analysis demonstrated the relevance of these three variables in determining risk of delays in child development, reinforcing the multifactorial dimension of NPMD .

Factors such as poverty and nutrition problems, highlighted in the present study as associated to NPMD, have already been mentioned in previous studies ${ }^{10,29}$.

In nutritional assessment, $52 \%(\mathrm{n}=40)$ of children showed some nutritional risk, with greater prevalence of obesity $(50.7 \%)$ than of malnutrition $(1.3 \%)$, validating previous studies 30 , but with an even higher proportion. These results confirm the nutritional transition process that has taken place, with a reduction in the prevalence of nutritional deficits and most expressive occurrences of overweight and obesity. Such overweight is occurring in developing countries, including Brazil ${ }^{31}$, and in different socioeconomic levels, even in children with lower economic conditions ${ }^{32}$.

Studies have confirmed the existence of a relation between low birth weight and changes in development ${ }^{33}$. This relation is considered a risk factor for changes in neuropsychomotor development, more pronounced when the newborn is exposed to unfavorable social conditions, such as parental education status, dysfunctional families, and family psychiatric problems ${ }^{34}$. These findings have already been indicated since $1996^{35}$ and revealed that Brazilian children at 12 months of age weighing less than $2,500 \mathrm{Kg}$ were three times more likely to present NPMD delays, as suggested by the Denver II test and confirmed in the study of Resegue et al. ${ }^{36}$. The same authors highlight this neonatal indicator as a necessary marker for the monitoring and supervision of the child development, and Caçola and Bobbio $^{33}$ claim that low birth weight is one of the main predictors of neonatal and perinatal morbidity and mortality.

Several studies $6,7,37$ have shown evidence of the negative impact of poverty and poor socioeconomic conditions in the NPMD during early life in various countries. Hoff ${ }^{38}$ states that the socioeconomic status of the family is a powerful predictor of many aspects of child development. Although studies use different methods to assess the socioeconomic level and the NPMD, they all indicate that such development is influenced by socioeconomic conditions. Thus, our study demonstrated that children with a monthly family income lower than $\mathrm{R} \$ 2,000.00$ were approximately nine times more likely to present questionable development. These results legitimate the studies of Halpern et al. ${ }^{39}$ and Paiva et $a l .{ }^{40}$. The researchers Halpern et al. ${ }^{39}$ evaluated the neuropsychomotor development of 1,363 children using the Denver II test, and found that children from low-income families were more likely $(50 \%)$ to present a suspected delay in their development, probably because of the stimulation and varied opportunities that children with better socioeconomic conditions have in the first year of life.

The study of Paiva et al. ${ }^{40}$ evaluated 136 children between nine and 12 months of age and found that infants with low socioeconomic conditions present more often suspected delays in NPMD, especially regarding receptive communication. This can be justified by the fact that families with low socioeconomic conditions tend to read less to their children, depriving them of complex verbal strategies.

A cohort study conducted by Lima et $a l .{ }^{41}$ in the northeastern of Brazil aimed at identifying biological and environmental factors associated with mental and motor development in the first 12 months of life among the lowincome population. It was found that environmental factors had a greater negative effect on the child's development and factors related to poverty had a greater influence on it. The results suggest that poverty directly affects the quality of domestic environment, mainly due to the lack of physical conditions and resources necessary to promote properly stimulation and child protection.

Halpern et al..$^{35}$ of the children evaluated at 12 months presented a development delay that was twice as frequent in the low-income children. To GranthamMcGregor et al. ${ }^{37}$, low-income children who do not reach all the potential of their development are less likely to become productive adults, mainly due to less years of schooling and less learning per year in school, which implies a decrease in income as adults, resulting in a cycle when forming their families, thus generating consequences to national development.

Although family income was presented as a risk factor in the present study, one might think that low-income children who do not attend daycare are at a larger risk. This lacks further explanation, considering daycare was identified in another study ${ }^{42}$ as having a protective effect in development, promoting cognitive and academic aspects, and even serving to reduce the differences influenced by socioeconomic factors. Thus, we suggest to future studies the comparison of factors here surveyed between children who attend and who do not attend daycare.

Among the risk factors selected for the analysis of the development of the children examined in the ECECs, paternal absence presented a significant correlation with the risk of delay in development.

Similar to our research, some studies indicate that paternal absence can be considered a risk factor for delays in development ${ }^{43}$, with the father being a key component for the development of the child ${ }^{44}$.

The research done by Pilz and Schermann ${ }^{45}$ in the city of Canoas/RS found, through the Denver II test, that $27 \%$ of the sample presented a suspected delay in neuropsychomotor development, which was seven times more likely in children whose mothers did not receive support from the fathers.

Yet, the study of Amorim et al. ${ }^{46}$ showed that a daily time in the company of the father was also statistically associated with higher percentages of delayed motor development. The authors associated this finding with the fact that paternal presence is usually linked to unemployment, which has an impact on other social conditions. Our study concluded that paternal absence has a negative influence on child development, but not the number of hours spent in the company of the father, which 
could be analyzed in future studies.

Anme et al..$^{47}$ have developed a longitudinal study in Japan and have concluded that fatherhood is a strong and consistent predictor of child development. In the referred study, the spousal support was considerably related to the development of the vocabulary of the children evaluated. This supports the findings of our study, since the paternal absence is linked to lack of family support.

The authors Manfroi, Macarini and Vieira ${ }^{44}$ concluded that the influence of the father in child development (social and motor) is connected to several factors. One factor is family harmony, since it favors a more affectionate involvement between mother and children. Another one is family dynamic, once father influence is responsible for transmitting values and setting an example for cooperation through the assistance in domestic activities. There is also the involvement in the basic care of the children (hygiene, food), which brings the family closer together, and games that increase the interaction between father and child.

Thus, it is concluded that the presence of the father has a protective effect on child development, due to the interaction and relationship with the child, the support to the mother and also the assistance in the socioeconomic factors of the house ${ }^{43}$. In addition, it reinforces the need for an evaluation that considers the family context.

Considering the different areas of development, language presented the most remarkable delay in the present study. Although more precise statements cannot be made due to the model of the study, paternal absence is considered an influencer. There are studies ${ }^{48}$ that show the paternal influence on the development of language and cognition, but further evidence is still needed.

During child development, situations of restraint, regardless of the reasons, can modify connections and superior functions in a deleterious way. Early assessment/ intervention have a crucial role in critical periods and situations of development. This is due to the fact that neuroplasticity has critical periods that are directly related to the potential of a functional recovery and must be known and prioritized in early intervention. It is known that, before the formation of neurons and glial cells, its migration, apoptosis' processes and formation of dendrites are fundamental events. After birth, during childhood, the formation of dendrites, the formation of synapses and the myelination process are the most important events ${ }^{49}$ : at 2 years of age, the formation of synapses is doubled in comparison to the number of synapses in adults, being strongly influenced by environmental issues ${ }^{50}$.

Considering the intense neuroplasticity during the first years of life, the interaction between the individual aspects, the environment in which the child is inserted and the tasks proposed, as well as the susceptibility to stimulation in school and/or daycare, cause changes in the psychomotor behavior. All this results in a full motor development, improvement of all capabilities and expansion of the psychomotor background.

The majority $(68.8 \%)$ of the children evaluated presented normal NPMD, but risks were identified in $31.2 \%$ of the children. These children could benefit from early intervention programs. The area that presented the best performance was fine motor-adaptive (3.75\%) and the one that presented the most questionable performance was the language area $(57.5 \%)$.

These findings can contribute to the field of public health through the systematization of strategies for health promotion and prevention. In addition, it can subsidize public policies for children's health.

Our study reinforces the systemic and multifactorial nature of NPMD, considering that low birth weight, monthly family income and paternal absence were the highest risk factors for the development of children in the daycare centers evaluated, which indicates the need for follow-up and monitoring.

\section{Acknowledgements}

The authors would like to thank the Academic Publishing Advisory Center (Centro de Assessoria de Publicação Acadêmica, CAPA - www.capa.ufpr.br) of the Federal University of Paraná for assistance with English language editing.

\section{REFERENCES}

1. Gannotti ME, Christy JB, Heathcock JC, Kolobe TH. A path model for evaluating dosing parameters for children with cerebral palsy. Phys Ther. 2014;94(3):411-21. DOI: http://dx.doi.org/10.2522/ptj.20130022

2. Albers EM, Riksen-Walraven JM, Weerth C. Developmental stimulation in child care centers contributes to young infants' cognitive development. Infant Behav Dev. 2010;33(4):401-8. DOI: http://dx.doi.org/10.1016/j.infbeh.2010.04.004

3. Guimarães FAB, Di Assis C, Vieira MEB, Formiga CKMR. Evaluation of teaching materials prepared for guidance of caregivers and day care teachers on child development. J Hum Growth Dev. 2015;25(1):2740. DOI: http://dx.doi.org/10.7322/jhgd.96764

4. Scola C, Bourjade M, Jover M. Social interaction is associated with changes in infants' motor activity. Socioaffect Neurosci Psychol. 2015;5:28256. DOI: http://dx.doi.org/10.3402/snp.v5.28256

5. Organização Mundial de Saúde (OMS). Classificação Internacional de Funcionalidade, Incapacidade e Saúde (CIF). São Paulo: EDUSP; 2015.

6. Walker SP, Wachs TD, Gardner JM, Lozoff B, Wasserman GA, Pollitt E, et al. Child development: risk factors for adverse outcomes in developing countries. Lancet. 2007;369(9556):145-57. DOI: http://dx.doi.org/10.1016/S0140-6736(07)60076-2

7. Chilton M, Chyatte M, Breaux J. The negative effects of poverty \& food insecurity on child development. 
Indian J Med Res. 2007;126(4):262-72.

8. Morgan C, Novak I, Badawi N. Enriched environments and motor outcomes in cerebral palsy: systematic review and meta-analysis. Pediatrics. 2013;132(3):e735-46. DOI: http://dx.doi.org/10.1542/peds.2012-3985

9. Franciotti DL, Mayer GN, Cancelier ACL. Fatores de risco para baixo peso ao nascer: um estudo de caso-controle. Arq Catarinenses Med. 2010;39(3):63-9.

10. Braga AKP, Rodovalho JC, Formiga CKMR. Evolução do crescimento e desenvolvimento neuropsicomotor de crianças pré-escolares de zero a dois anos do município de Goiânia (GO). Rev Bras Crescimento Desenvolvimento Hum. 2011;21(2):230-9. DOI: http://dx.doi.org/10.7322/jhgd.20011

11. Halpern R, Giugliani ERJ, Victora CG, Barros FC, Horta BL. Fatores de risco para suspeita de atraso no desenvolvimento neuropsicomotor aos 12 meses de vida. J Pediatr. 2000;76(6):421-8.

12. Campos MM, Esposito YL, Bhering E, Gimenes N, Abuchaim B. A qualidade da educação infantil: um estudo em seis capitais brasileiras. Cad Pesqui. 2011;41(142):20-54. DOI: http://dx.doi.org/10.1590/S0100-15742011000100003

13. Setodji CM, Le VN, Schaack D. Using generalized additive modeling to empirically identify thresholds within the ITERS in relation to toddlers' cognitive development. Dev Psychol. 2013;49(4):632-45. DOI: http://dx.doi.org/10.1037/a0028738

14. Macy M. Promising Practices, Models, and Research in the Early Identification of Young Children with Disabilities. J Intellectual Disab Diagn Trat. 2015;3(4):154-5.

15. Cioni G, Inguaggiato E, Sgandurra G. Early intervention in neurodevelopmental disorders: underlying neural mechanisms. Dev Med Child Neurol. 2016;58(Suppl 4):61-6. DOI: http://dx.doi.org/10.1111/dmcn.13050

16. Nobre FDA, Carvalho AEV, Martinez FE, Linhares MBM. Estudo longitudinal do desenvolvimento de crianças nascidas pré-termo no primeiro ano pós-natal. Psicol Reflex Crit. 2009;22(3):362-9. DOI: http://dx.doi.org/10.1590/S0102-79722009000300006

17. Hwang AW, Liao HF, Granlund M, Simeonsson RJ, Kang LJ, Pan YL. Linkage of ICF-CY codes with environmental factors in studies of developmental outcomes of infants and toddlers with or at risk for motor delays. Disabil Rehabil. 2014;36(2):89-104.DOI: http://dx.doi.org/10.3109/09638288.2013.777805

18. Hwang AW, Liao HF, Chen PC, Hsieh WS, Simeonsson RJ, Weng LJ, et al. Applying the ICF-CY framework to examine biological and environmental factors in early childhood development. J Formos Med Assoc. 2014 May;113(5):303-12. DOI: http://dx.doi.org/10.1016/j.jma.2011.10.004

19. Santos D, Tolocka R, Carvalho J, Heringer L, Almeida C, Miquelote A. Gross motor performance and its association with neonatal and familial factors and day care exposure among children up to three years old. Rev Bras Fisioter. 2009;13(2):173-9. DOI: http://dx.doi.org/10.1590/S1413-35552009005000025

20. Baltieri L, Santos DCC, Gibim NC, Souza CT, Batistela ACT, Tolocka RE. Motor performance of infants attending the nurseries of public day care centers. Rev Paul Pediatr. 2010;28(3):283-9. DOI: http://dx.doi.org/10.1590/S0103-05822010000300005

21. Souza CT, Santos DC, Tolocka RE, Baltieri L, Gibim NC, Habechian FA. Assessment of global motor performance and gross and fine motor skills of infants attending day care centers. Rev Bras Fisioter. 2010;14(4):309-15. DOI: http://dx.doi.org/10.1590/S1413-35552010000400007

22. Faul F, Erdfelder E, Lang AG, Buchner A. G* Power 3: A flexible statistical power analysis program for the social, behavioral, and biomedical sciences. Behav Res Methods. 2007;39(2):175-91.

23. Frankenburg WK, Dodds J, Archer P, Shapiro H, Bresnick B. The Denver II: a major revision and restandardization of the Denver Developmental Screening Test. Pediatrics. 1992;89(1):91-7.

24. Souza SC, Leone C, Takano OA, Moratelli HB. Desenvolvimento de pré-escolares na educação infantil em Cuiabá, Mato Grosso, Brasil. Cad Saúde Pública. 2008;24(8):1917-26. DOI: http://dx.doi.org/10.1590/S0102-311X2008000800020

25. WHO Multicentre Growth Reference Study Group. WHO Child Growth Standards based on length/ height, weight and age. Acta Paediatr. Suppl. 2006;450:76-85.

26. Rezende MA, Costa PS, Pontes PB. Triagem de desenvolvimento neuropsicomotor em instituições de educação infantil segundo o teste de Denver II. Esc. Anna Nery. 2005;9(3): 348-55. DOI: http://dx.doi.org/10.1590/S1414-81452005000300003

27. Sabatés AL, Mendes LCO. Perfil do crescimento e desenvolvimento de crianças entre 12 e 36 meses de idade que freqüentam uma creche municipal da cidade de Guarulhos. Ciênc Cuidado Saúde. 2007;6(2):164-70. DOI: http://dx.doi.org/10.4025/cienccuidsaude.v6i2.4143

28. Torquato JA, Paes JB, Bento MCC, Saikai GMPN, Souto JN, Lima EAM, et al. Prevalência de atraso do desenvolvimento neuropsicomotor em pré-escolares. Rev Bras Crescimento Desenvolvimento Hum. 2011;21(2):259-68. DOI: http://dx.doi.org/10.7322/jhgd.20014

29. Silva ACD, Engstron EM, Miranda CT. Fatores associados ao desenvolvimento neuropsicomotor em crianças de 6 a 18 meses de vida inseridas em creches públicas 
do município de João Pessoa, Paraíba, Brasil. Cad Saúde Pública. 2015;31(9):1881-93.

DOI: http://dx.doi.org/10.1590/0102-311X00104814

30. Biscegli TS, Corrêa CEC, Romera J, Hernandez JLJ. Avaliação do estado nutricional e prevalência da carência de ferro em crianças freqüentadoras de uma creche. Rev Paul Pediatr. 2006;24(4):323-9.

31. Batista Filho M, Rissin A. A transição nutricional no Brasil: tendências regionais e temporais. Cad. Saúde Pública. 2003;19(Suppl.1): S181-91. DOI: http://dx.doi.org/10.1590/S0102-311X2003000700019

32. Ebbeling CB, Pawlak DB, Ludwig DS. Childhood obesity: public-health crisis, common sense cure. Lancet. 369(9331):473-82. DOI: http://dx.doi.org/10.1016/S0140-6736(02)09678-2

33. Caçola P, Bobbio TG. Baixo peso ao nascer e alterações no desenvolvimento motor: a realidade atual. Rev Paul Pediatr. 2010;8(1):70-6. DOI: http://dx.doi.org/10.1590/S0103-05822010000100012

34. Resegue R, Puccini RF, Silva EMK. Fatores de risco associados a alterações no desenvolvimento da criança. Pediatria. 2007;29(2):117-28.

35. Halpern R, Barros FC, Horta BL, Victora CG. Desenvolvimento neuropsicomotor aos 12 meses de idade em uma coorte de base populacional no Sul do Brasil: diferenciais conforme peso ao nascer e renda familiar. Cad Saúde Pública. 1996;12(Supl.1):73-8. DOI: http://dx.doi.org/10.1590/S0102-311X1996000500011

36. Resegue R, Puccini RF, Silva EMK. Risk factors associated with developmental abnormalities among high-risk children attended at a multidisciplinary clinic. Sao Paulo Med. J. 2008;126(1):4-10. DOI: http://dx.doi.org/10.1590/S1516-31802008000100002

37. Grantham-McGregor S, Cheung YB, Cueto S, Glewwe P, Richter L, Strupp B, et al. Developmental potential in the first 5 years for children in developing countries. Lancet. 2007;369(9555):60-70. DOI: http://dx.doi.org/10.1016/S0140-6736(07)60032-4

38. Hoff E. The specificity of environmental influence: Socioeconomic status affects early vocabulary development via maternal speech. Child Dev. 2003;74(5):1368-78. DOI: http://dx.doi.org/10.1111/1467-8624.00612

39. Halpern R, Giugliani ER, Victora CG, Barros FC, Horta BL. Fatores de risco para suspeita de atraso no desenvolvimento neuropsicomotor aos 12 meses de vida. Rev Chil Pediatr. 2002;73(5):529-39. DOI: http://dx.doi.org/10.4067/S0370-41062002000500016

40. Paiva GS, Lima ACVMS, Lima MC, Eickmann SH. The effect of poverty on developmental screening scores among infants. Sao Paulo Med J. 2010;28(5):276-83. DOI: http://dx.doi.org/10.1590/S1516-31802010000500007

41. Lima MC, Eickmann SH, Lima AC, Guerra MQ, Lira PI, Huttly SR, et al. Determinants of mental and motor development at 12 months in a low income population: a cohort study in northeast Brazil. Acta Paediatr. 2004;93(7):969-75. DOI: http://dx.doi.org/10.1111/j.1651-2227.2004.tb18257.x

42. Laurin JC, Geoffroy MC, Boivin M, Japel C, Raynault MF, Tremblay RE, et al. Child care services, socioeconomic inequalities, and academic performance. Pediatrics. 2015;136(8). DOI: http://dx.doi.org/10.1542/peds.2015-0419

43. Barros KMFT, Fragoso AGC, Oliveira ALB, Cabral Filho JE, Castro RM. Influências do ambiente podem alterar a aquisição de habilidades motoras? Uma comparação entre préescolares de creches públicas e escolas privadas. Arq. Neuropsiquiatr. 2003;61(2A):170-5. DOI: http://dx.doi.org/10.1590/S0004-282X2003000200002

44. Manfroi EC, Macarini SM, Vieira ML. Comportamento parental e o papel do pai no desenvolvimento infantil. Rev Bras Crescimento Desenvolvimento Hum. 2011; 21(1):59-69. DOI: http://dx.doi.org/10.7322/jhgd.19996

45. Pilz EML, Schermann LB. Determinantes biológicos e ambientais no desenvolvimento neuropsicomotor em uma amostra de crianças de Canoas/RS. Ciênc Saúde Coletiva. 2007;12(1):182-90. http://dx.doi.org/10.1590/S1413-81232007000100021

46. Amorim RCA, Laurentino GEC, Barros KMFT, Ferreira ALPR, Moura Filho AG, Raposo MCF. Family health program: proposal for identification of risk factors for neuropsychomotor development. Rev Bras Fisioter. 2009;13(6):506-13. DOI: http://dx.doi.org/10.1590/S1413-35552009005000065

47. Anme T, Tanaka E, Shinohara R, Sugisawa Y, Watanabe T, Tomisaki E, et al. Center-based child extended care: Implications for young children's development in a five-year follow-up. Sci Res. 2012;2(4):435-40. DOI: http://dx.doi.org/10.4236/sm.2012.24056

48. Malmberg LE, Lewis S, West A, Murray E, Sylva K, Stein A. The influence of mothers' and fathers' sensitivity in the first year of life on children's cognitive outcomes at 18 and 36 months. Child Care Health Dev. 2016;42(1):1-7. DOI: http://dx.doi.org/10.1111/cch.12294

49. Hadders-Algra M. Challenges and limitations in early intervention. Dev Med Child Neurol. 2011;53(Suppl 4):52-5. DOI: http://dx.doi.org/10.1111/j.1469-8749.2011.04064.x

50. Johnston MV. Plasticity in the developing brain: implications for rehabilitation. Dev Disabil Res Rev. 2009;15(2):94-101. DOI: http://dx.doi.org/10.1002/ddrr.64 


\section{Resumo}

Introdução: Os primeiros anos de vida são fundamentais para o desenvolvimento neuropsicomotor (DNPM), neste período as crianças estão propensas a sofrer influências de fatores orgânicos, ambientais ou de atividades que podem ser protetores ou de risco para um desenvolvimento pleno com repercussões até a vida adulta.

Objetivo: O presente estudo teve como objetivo analisar o desenvolvimento neuropsicomotor (DNPM) de crianças de zero a três anos de idade e os fatores de risco associados ao desenvolvimento.

Método: Estudo transversal, abordagem contextual, baseada na CIF, por meio do Teste de Triagem de Denver II e avaliações complementares do estado nutricional. Na avaliação foram considerados os domínios da Classificação Internacional de Funcionalidade Incapacidade e Saúde (CIF) de funções e estrutura (questionário de avaliação), atividades e participação (avaliação do DNPM na escola), fatores pessoais (características familiares) e fatores ambientais (características dos CEIs). Os instrumentos de avaliação consistiram em um questionário com informações sobre a criança, características atuais, neonatais e familiares. Para avaliação do DNPM, utilizou-se o teste de Denver II. Na análise estatística realizou-se a calibração pelo índice Kappa de concordância intra e inter-avaliadores e posteriormente a regressão logística utilizando como seleção de modelo Logit com resposta binária e método Stepwise (Backward); a construção de uma curva ROC (Receiver Operating Characteristic) para definir o perfil de explicabilidade do modelo construído; o cálculo do Odds Ratio (OR), a razão de chances de ocorrência de uma variável estar associada com o DNPM.

Resultados: O DNPM encontrou-se dentro dos parâmetros de normalidade em 68,8\% ( $n=53$ ) e com riscos de atrasos em 31,2\% $(n=24)$. A área de melhor desempenho foi a motora fina -adaptativa $(3,75 \%)$ e a mais questionável foi da linguagem $(57,5 \%)$. Foi acurado que $52 \%(n=40)$ das crianças apresentaram algum risco nutricional. Verificou-se que o baixo peso ao nascer (OR=181), a renda familiar mensal $(O R=9)$ e a ausência do pai $(O R=34)$ são fatores estatisticamente significantes sobre o risco de atrasos no DNPM.

Conclusão: O baixo peso ao nascer, a renda familiar e a ausência do pai estão associados com riscos de atraso do DNPM. Estes achados reforçam a natureza sistêmica e multifatorial do DNPM e comprova a necessidade de acompanhamento, monitoramento e criação de políticas públicas, especialmente em crianças com condições desfavoráveis, que contribuam para o desenvolvimento pleno das crianças, uma vez que instituições de educação infantil do ensino público devem ser agentes transformadoras na qualidade do desenvolvimento infantil.

Palavras-chave: fisioterapia, desenvolvimento infantil, educação infantil, promoção da saúde.

(๑) The authors (2017), this article is distributed under the terms of the Creative Commons Attribution 4.0 International License (http://creativecommons.org/licenses/by/4.0/), which permits unrestricted use, distribution, and reproduction in any medium, provided you give appropriate credit to the original author(s) and the source, provide a link to the Creative Commons license, and indicate if changes were made. The Creative Commons Public Domain Dedication waiver (http://creativecommons.org/publicdomain/ zero/1.0/) applies to the data made available in this article, unless otherwise stated. 